\title{
Structure function analysis of $P$. falciparum VAR2CSA
}

\author{
Madeleine Dahlbäck', Lars M Jørgensen', Stig Christoffersen², Morten A Nielsen', Thor G Theander', \\ David E Arnot ${ }^{1}$, Sine Larsen ${ }^{2}$, Ali Salanti ${ }^{1 *}$ \\ From Parasite to Prevention: Advances in the understanding of malaria \\ Edinburgh, UK. 20-22 October 2010
}

\section{Background}

In pregnant women, $P$. falciparum-infected erythrocytes (IEs) express a unique member of the PfEMP1 family named VAR2CSA, which is associated with the ability of the IEs to adhere to chondroitin sulphate A (CSA) in the placenta [1]. Understanding the mechanism behind this specific CSA interaction is important for the optimal design of a vaccine against placental malaria. CSAbinding of single domains of VAR2CSA has appeared to not reflect the specificity of the native IE binding [2].

\section{Materials and methods}

We have shown that full length recombinant VAR2CSA binds with high affinity to CSA [3]. To define important regions we produced a panel of $\mathrm{N}$ and $\mathrm{C}$-terminal truncated VAR2CSA proteins. Proteins were expressed in baculovirus infected insect cells and purified by affinity chromatography followed by size exclusion chromatography. Affinity measurements were done on an Attana biosensor and structural analysis (SAXS) was performed in Grenoble.

\section{Results}

Structural analysis of theVAR2CSA recombinant proteins shows that the protein is structured with a large compact head structure where the minimum CSA binding region is also located.

\section{Conclusion}

The minimum CSA binding region ofVAR2CSA spans several single domains; this is in line with data showing that several single domains can induce adhesion blocking antibodies. It remains to be investigated if the minimum binding region is a better vaccine construct than the proposed single domains.

\section{Author details}

${ }^{1}$ Centre for Medical Parasitologyat Department of International Health, Immunology and Microbiology, University of Copenhagen CSS, Øster Farimagsgade 5 A, DK-1014 Copenhagen K, Denmark. 'Department of Chemistry University of Copenhagen, Universitetsparken 5, 2100

Copenhagen, Denmark.

\section{Published: 20 October 2010}

\section{References}

1. Salanti A, Dahlbäck M, Turner L, Nielsen MA, Barfod L, Magistrado P, Jensen AT, Lavstsen T, Ofori MF, Marsh K, Hviid L, Theander TG: Evidence for the involvement of VAR2CSA in pregnancy-associated malaria. J Exp Med 2004, 200:1197-203.

2. Resende M, Ditlev SB, Nielsen MA, Bodevin S, Bruun S, Pinto W, Clausen $H$, Turner L, Theander TG, Salanti A, Dahlbäck M: Chondroitin sulphate A (CSA)-binding of single recombinant Duffy-binding-like domains is not restricted to Plasmodium falciparum Erythrocyte Membrane Protein 1 expressed by CSA-binding parasites. Int J Parasitol 2009, 39:1195-204.

3. Khunrae P, Dahlbäck M, Nielsen MA, Andersen G, Ditlev SB, Resende M, Pinto W, Theander TG, Higgins MK, Salanti A: Full-length recombinant Plasmodium falciparum VAR2CSA binds specifically to CSPG and induces potent parasite adhesion-blocking antibodies. J Mol Biol 2010, 97:826-34.

doi:10.1186/1475-2875-9-S2-14

Cite this article as: Dahlbäck et al:: Structure function analysis of P. falciparum VAR2CSA. Malaria Journal 2010 9(Suppl 2):14. 